\title{
COMPREHENSIVE HIGH-RESOLUTION GENOMIC PROFILING AND CYTOGENETICS OF HUMAN CHONDROCYTE CULTURES BY GTG- BANDING, LOCUS-SPECIFIC FISH, SKY AND SNP ARRAY
}

\author{
M. Wallenborn ${ }^{1,}$, O. Petters ${ }^{2 \S}$, D. Rudolf ${ }^{1}$, H. Hantmann ${ }^{1}$, M. Richter ${ }^{1}$, P. Ahnert ${ }^{3}$, L. Rohani ${ }^{1}$, J.J. Smink ${ }^{4}$, G.C. \\ Bulwin ${ }^{4}$, W. Krupp 5 , R.M. Schulz ${ }^{2}$ and H. Holland ${ }^{1, *}$ \\ ${ }^{1}$ Translational Centre for Regenerative Medicine (TRM) and Saxonian Incubator for Clinical Translation \\ (SIKT), University of Leipzig, Leipzig, Germany \\ ${ }^{2}$ Clinic of Orthopaedics, Traumatology and Plastic Surgery, Faculty of Medicine, University of Leipzig, \\ Leipzig, Germany \\ ${ }^{3}$ Institute for Medical Informatics, Statistics and Epidemiology (IMISE), University of Leipzig, \\ Leipzig, Germany \\ ${ }^{4}$ co.don ${ }^{\circledR}$ AG, Teltow, Germany \\ ${ }^{5}$ Department of Neurosurgery, University of Leipzig, Leipzig, Germany \\ $\S$ These authors contributed equally to this work
}

\begin{abstract}
In the development of cell-based medicinal products, it is crucial to guarantee that the application of such an advanced therapy medicinal product (ATMP) is safe for the patients. The consensus of the European regulatory authorities is: "In conclusion, on the basis of the state of art, conventional karyotyping can be considered a valuable and useful technique to analyse chromosomal stability during preclinical studies".

408 chondrocyte samples (84 monolayers and 324 spheroids) from six patients were analysed using trypsin-Giemsa staining, spectral karyotyping and fluorescence in situ hybridisation, to evaluate the genetic stability of an ATMP named Spherox ${ }^{\circledR}$. Single nucleotide polymorphism (SNP) array analysis was performed on chondrocyte spheroids from five of the six donors.

Applying this combination of techniques, the genetic analyses performed revealed no significant genetic instability until passage 3 in monolayer cells and interphase cells from spheroid cultures at different time points. Clonal occurrence of polyploid metaphases and endoreduplications were identified associated with prolonged cultivation time. Also, gonosomal losses were observed in chondrocyte spheroids, with increasing passage and duration of the differentiation phase. Interestingly, in one of the donors, chromosomal aberrations that are also described in extraskeletal myxoid chondrosarcoma were identified. The SNP array analysis exhibited chromosomal aberrations in two donors and copy neutral losses of heterozygosity regions in four donors.

This study showed the necessity of combined genetic analyses at defined cultivation time points in quality studies within the field of cell therapy.
\end{abstract}

Keywords: ATMP, CBMP, cell therapy, chondrocyte, GTG-banding, spectral karyotyping, SNP array.

*Address for correspondence: H. Holland, Saxonian Incubator for Clinical Translation (SIKT) and Faculty of Medicine, University of Leipzig, Philipp-Rosenthal Str. 55, D-04103 Leipzig, Germany.

Telephone number: +493419739660Ｅmail: Heidrun.Holland@medizin.uni-leipzig.de

Copyright policy: This article is distributed in accordance with Creative Commons Attribution Licence (http://creativecommons.org/licenses/by-sa/4.0/).

\section{List of abbreviations}

ACI autologous chondrocyte implantation

ACT autologous chondrocyte transplantation

AG incorporated company

ATMP advanced therapy medicinal product

CBMP cell-based medicinal products
CEP centromere-specific

CGH comparative genomic hybridisation

ChAS chromosome analysis suite

cn copy neutral

CNV copy number variation

ECM extracellular matrix

EMA European Medicines Agency 
EMC extraskeletal myxoid chondrosarcoma

FISH fluorescence in situ hybridisation

GMP good manufacturing practice

GTG Giemsa staining

HIV human immunodeficiency virus

IC interphase cells

ICRS International Cartilage Research Society

ISCN International system for human cytogenetic nomenclature

LOH loss of heterozygosity

Mbp mega base pairs

MC metaphase cells

MSC mesenchymal stromal cells

NER nucleotide excision repair

$\mathrm{P}$ passage

PDL population doubling level

SKY spectral karyotyping

SNP single nucleotide polymorphism

UPD uniparental disomy

WHO World Health Organization

\section{Introduction}

With the development of CBMP, the safety of cellular components is becoming increasingly relevant. Therefore, the potential tumorigenic risk in vivo due to the implantation of genetically unstable or modified cells should be identified in advance with in vitro studies regarding the quality - in particular, the stability - of the applied cells. Various genetic analytical techniques could be considered for this approach. In general, GTG-banding, complemented, if necessary, with locus-specific FISH, SKY and SNP array or CGH, is considered by the EMA as a useful analytical method to prove genetic stability of an ATMP candidate (Barkholt et al., 2013).

A variety of numerical and/or structural genetic changes, including clonal changes, may occur in CBMPs. Considering potential neoplastic changes, clonal developments are defined as cell populations if they are derived from a single progenitor cell, as also described by the current ISCN criteria (McGowanJordan et al., 2016). If several cells display the same - or highly similar - chromosomal aberrations, they are commonly considered to have a clonal origin. Therefore, these clonal cells do not have to occur homogeneously, as subclones could also have developed from these clonal cells. A clonal origin can be assumed when gained chromosomal material (e.g. polyploidy) or structural rearrangements are present in at least two different cells (McGowan-Jordan et al., 2016). Ideally, these aberrations are discovered in distinct primary cultivation vessels.

Polyploidy is considered to be a disturbed distribution of a complete chromosome set, resulting in a more than diploid chromosome set in the corresponding cells. Healthy cells with a high transcription rate, for example liver cells, may sometimes show polyploidy. However, polyploidy is also found in tumour tissue (Andriani et al.,
2016). Endoreduplication is the replication of the chromosomes without chromatid separation or cytokinesis (McGowan-Jordan et al., 2016). Higher frequencies of cells with endoreduplication are observed in human trophoblast cells and tumour cells (Therman, 1995).

ATMPs are medicines for human use based on genes or cells. A few advanced therapies, including two tissue-engineered products for articular cartilage repair, have successfully passed the centralised European marketing authorisation procedures (ChondroCelect ${ }^{\circledR}$ and MACI: matrix-applied characterised autologous cultured chondrocytes). ACT is a surgical treatment modality that repairs focal lesions and ideally regenerates the articular cartilage in the knee joint. ACT may provide pain relief, increase knee function and potentially prevent partial or total knee joint replacement surgery due to secondary osteoarthritis (Hunziker et al., 2015). Independent of the generation of the ACT product, this cell-based articular cartilage repair procedure takes place in three stages. In a first stage, usually 200-300 mg of cartilage are sampled arthroscopically from an area of decreased weight-bearing, either from the intercondylar notch or the superior ridge of the medial or lateral femoral condyle of the patient. In a second stage, the extracellular matrix of the biopsy is removed enzymatically and the chondrocytes are isolated. These cells are grown in vitro in a GMP laboratory for up to 6 weeks in two-dimensional (2D) monolayer cultures and/or in various biomaterials in three-dimensions (3D). In a third stage, the patient undergoes a second surgical treatment, in which the respective (matrix-coupled) ACT products are applied to the debrided area of the lesion. Chondrocytes in the graft should adapt themselves to their new environment by forming new hyalinelike cartilage in the mid- and long-term (Brittberg, 2012). Spherox ${ }^{\circledR}$ (co.don ${ }^{\circledR}$ AG, Teltow, Germany), formerly known as Chondrosphere ${ }^{\circledR}$, is an ACTATMP consisting of chondrocytes that are initially propagated in monolayer cultures until P 3 and, subsequently, transformed into spheroids containing chondrocytes and an endogenously produced extracellular matrix, with no use of an exogenous scaffold (Anderer and Libera, 2002). To obtain an EU-wide marketing authorisation, in 2013, Barkholt et al. performed further investigations - particularly regarding safety, including cellular stability - on Spherox ${ }^{\circledR}$, to rule out any side effect and risk of the treatment method, as requested by the EMA.

Since osteoarthritis is mainly a disease of elderly patients, there might be a theoretical risk of age-, disease- and/or cultivation-dependent occurrence of chromosomal aberrations. After prolonged cultivation of cells, it is generally possible that numerical or structural chromosomal aberrations, mainly clonal changes, occur as cultivation-related events. Such genetic instability is shown for many different cell types after a prolonged cultivation (Gardner et al., 2012). For those reasons, it is important 
that only cells that are cultivated for a short time, with few PDLs, thereby remaining close to the in vivo situation, are used for ATMPs. In addition, this may also require comprehensive safety analyses of cells to be transplanted to rule out malignant changes or chromosomal aberrations (Boyle et al., 2006). So far, there are no indications that cells with only a limited number of doublings outside the human body would cause tumorigenesis (Barkholt et al., 2013). Comprehensive genetic data in cell therapy are limited but necessary to provide more detailed information about genetic stability. As previously demonstrated, the detection rate of chromosomal aberrations can be optimised by combining complementary cytogenetic and molecular techniques for tumour cell analyses (Xu et al., 2015; Holland et al., 2012).

Analyses of human chondrocytes of post-mortem donors and donors scheduled for scaffold-assisted ACT, using GTG-banding and FISH, are first described by Trimborn et al. (2012). In contrast to post-mortem donors, no clonal chromosomal aberrations are observed in the ACT donors. Postmortem chondrocytes show up to $26.7 \%$ numerical chromosomal aberrations, such as autosomal gains of chromosomes 5, 7 and 8 and gonosomal gains and losses, while chondrocytes of donors scheduled for ACT show up to $1.3 \%$ numerical chromosomal aberrations. Single structural chromosomal aberrations in living donors scheduled for ACT include inversions, translocations, losses/gains of gonosomes, gains of chromosomes 5, 7 and 8 and marker chromosomes (Trimborn et al., 2012). Stumm et al. (2012), in a study on genomic chondrocyte culture profiling by array-CGH and FISH, show autosomal stability but also variable loss of $\mathrm{Y}$ chromosome in all male samples in monolayer. Although losses of $Y$ chromosomes may represent age-related processes, these data suggest some caution toward applying cultivation processes to chondrocytes from elderly patients for cell-based therapy. Williams et al. (2010), in a study on cytogenetic analyses of a progenitor cell sub-population in human articular cartilage, demonstrate that cartilage progenitors with a PDL of 31.3 are to the largest extent normal, but with some chromosomal aberrations that are likely linked to the high PDL and cultivation conditions. This was particularly apparent in the non-recurrent deletion of the short arm of the chromosome 20.

Combining different genetic techniques more precisely defines potential genomic instabilities and the resulting tumorigenic risks of ATMP products, which should be investigated during cell quality/

Table 1. Properties of biopsy material used for production of Spherox ${ }^{\circledR}$ and for subsequent (molecular) cytogenetic analyses.

\begin{tabular}{|c|c|c|c|c|c|}
\hline Patient & Sample material & Gender & Age (years) & Diagnosis & Therapy \\
\hline 1 & Femoral condyle, tibia plateau & Female & 79 & Gonarthrosis & Endoprothesis \\
\hline 2 & Femoral condyle, tibia plateau & Male & 73 & Primary gonarthrosis & Endoprothesis \\
\hline 3 & Femoral condyle, tibia plateau & Male & 55 & Primary gonarthrosis & Endoprothesis \\
\hline 4 & Femoral condyle & Female & 66 & Gonarthrosis & Endoprothesis \\
\hline 5 & Femoral condyle, tibia plateau & Female & 50 & Gonarthrosis & Endoprothesis \\
\hline 6 & Femoral condyle & Female & 69 & Gonarthrosis & Endoprothesis \\
\hline
\end{tabular}

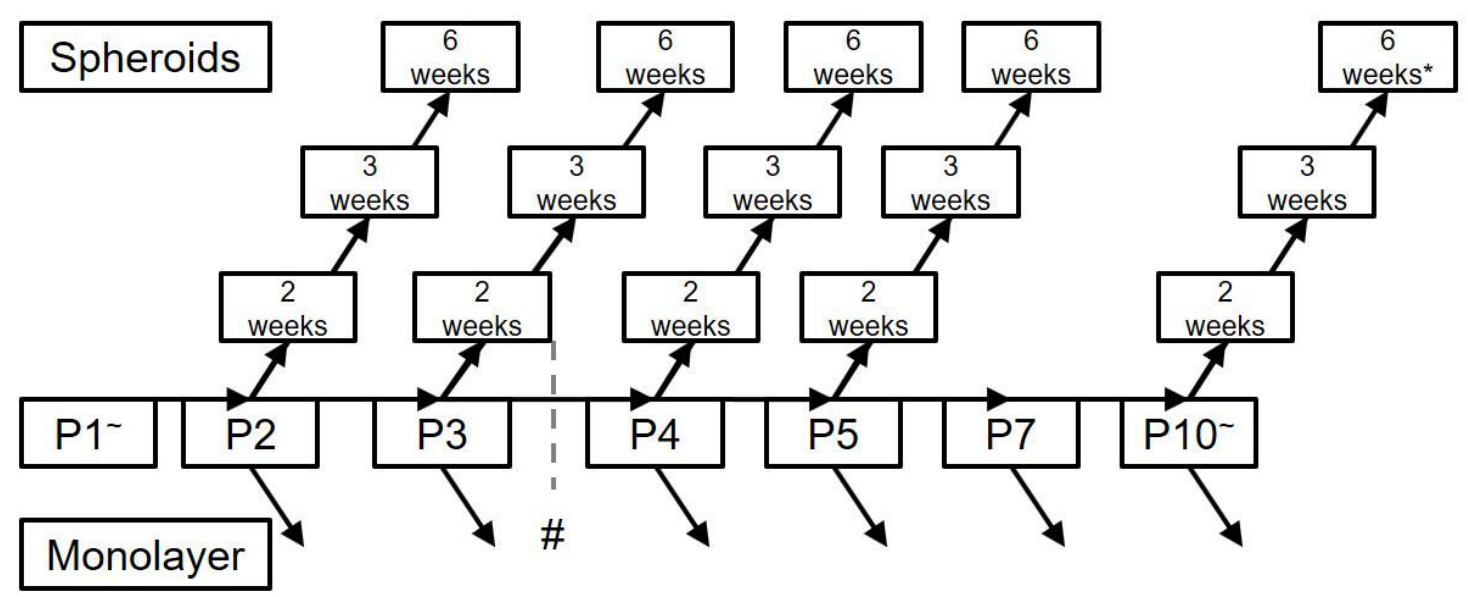

Fig. 1. Monolayer cultures and spheroids differentiated for a variable time were used. Cells at P 4 and higher P (\#) are not utilised for the routine GMP production process of Spherox ${ }^{\circledR}$ by $\cos$ don ${ }^{\circledR}$ AG. The differentiation phase after P 10 was 7 weeks in patient 1 and 5 weeks in patient 6 , instead of the standard 6 weeks $\left({ }^{*}\right)$. No data were available from monolayer culture of patient 1 in P 1 and P $10(\sim)$. 
Table 2. Cumulative PDL and P for patient 2 to 6 . For patient 1, data were not recorded. ${ }^{*}$ The GMP production of Spherox ® was only used until passage 3.

\begin{tabular}{|l|c|c|c|c|c|c|c|c|c|c|c|}
\hline Passage & P 1 & P 2 & P 3* & P 4 & P 5 & P 6 & P & P 8 & P 9 & P 10 \\
\hline Patient 1 & \multicolumn{9}{|c|}{ n.a. } \\
\hline Patient 2 & 1.94 & 3.78 & 6.14 & 8.17 & 10.02 & 12.49 & 14.24 & 15.88 & 17.53 & 18.67 \\
\hline Patient 3 & 1.84 & 3.70 & 6.05 & 8.38 & 10.41 & 11.83 & 13.91 & 15.80 & 17.70 & 20.14 \\
\hline Patient 4 & 6.19 & 8.27 & 10.17 & 12.01 & 13.86 & 15.03 & 15.40 & 16.03 & 16.64 & 16.99 \\
\hline Patient 5 & 2.35 & 5.55 & 8.07 & 10.23 & 12.06 & 13.85 & 14.88 & 16.39 & 17.82 & 19.25 \\
\hline Patient 6 & 2.58 & 5.68 & 8.08 & 10.07 & 12.24 & 13.50 & 14.86 & 15.81 & 17.14 & 18.30 \\
\hline Mean & 2.98 & 5.40 & 7.70 & 9.77 & 11.72 & 13.34 & 14.66 & 15.98 & 17.37 & 18.67 \\
\hline SD & 1.82 & 1.86 & 1.70 & 1.57 & 1.55 & 1.24 & 0.59 & 0.25 & 0.48 & 1.17 \\
\hline
\end{tabular}

stability studies based on the envisaged GMP production process. Therefore, a comprehensive genetic analysis of multiple $2 \mathrm{D}$ and $3 \mathrm{D}$ cultivation stages of six chondrocyte donors using GTG-banding, SKY, FISH and genome wide SNP array $(n=5)$ was performed. The aim of the present study was to evaluate the genetic stability of these chondrocyte cultures that were processed in close analogy to the current GMP production process of Spherox ${ }^{\circledR}$, which is intended for application in ACT.

\section{Materials and Methods}

\section{Patient material}

The chondrocyte monolayer cultures (84 samples) and the spheroids (324 samples) used for the analyses of genetic stability or chromosomal aberrations were derived from biopsies of residual joint samples of 6 patients, who underwent total knee joint replacement surgery, with written informed consent of the patient and ethics permission [AS 126(bB)/2017] for use of the material for research purposes only. Processed cartilage was taken from undamaged areas of elderly patients with degenerated osteoarthritic cartilage, which does not correspond to the healthy cartilage normally used during the manufacturing process of ACTs. The harvested biopsy material, patient characteristics, diagnosis and treatment are summarised in Table 1 . With regard to the age of the patients, biopsy material does not comply with the specification for production of the Spherox ${ }^{\circledR}$ in the context of the approved production process of the co.don ${ }^{\circledR}$ AG.

\section{Chondrocyte isolation and 2D and 3D cultivation of chondrocyte samples}

Cells were cultured at co.don ${ }^{\circledR}$ AG under GMPanalogue conditions, including microbiological monitoring. At several time points during monolayer expansion and 3D cultivation, samples were collected for genetic stability analyses (Fig. 1). Chondrocyte isolation from articular cartilage, their monolayer expansion and the generation of spheroids were performed as described previously (Anderer and Libera, 2002).
In detail, cartilage tissue was removed from the residing knee joint sample and minced. The chondrocytes were released from the cartilage tissue by enzymatic digestion using collagenase/protease solution at $37^{\circ} \mathrm{C}$ overnight. Cells were cultured in cell culture medium (Biochrom $\mathrm{GmbH}$, now part of Merck), supplemented with $10 \%$ human pool serum (pooled from about 15 donors), no growth factors, antibiotics or other supplements were added. The human serum was derived from the manufacturing department and each batch was tested for the presence of several viruses: HIV, Hepatitis B and $\mathrm{C}$ and Syphilis. Cell culture medium was refreshed twice a week. The cells were cultured to $100 \%$ confluency. After reaching confluence, the cells were passaged by removing the cell culture medium followed by careful rinsing with phosphate-buffered saline (PBS) and by enzymatic release of the cells by adding papain for $5 \mathrm{~min}$ at $37^{\circ} \mathrm{C}$. Monolayer cells were cultivated until P 10. To produce spheroids, $2 \times 10^{5}$ cells of the respective monolayer passage (P 2, P 3, P 4, P 5 and P 10) were seeded onto coated non-adherent 96-well plates and cell culture medium supplemented with $10 \%$ autologous serum (co.don ${ }^{\circledR}$ AG; the donors of the serum were patients who received a transplant from the company) was added. Under these conditions, the chondrocytes aggregated into spheroids. Medium was changed twice a week. The spheroids were cultured at $37^{\circ} \mathrm{C}$ in a humidified atmosphere and $5 \% \mathrm{CO}_{2}$ for 2, 3 and 6 weeks.

The cumulated PDLs per passage are given in Table 2.

Table 3a. Overview of samples for GTG and SKY analyses of chondrocyte monolayers.

\begin{tabular}{|l|c|c|c|c|c|c|c|}
\hline Passage & P 1 & P 2 & P 3 & P 4 & P 5 & P 7 & P 10 \\
\hline Patient 1 & n.a. & x & x & x & x & x & n.a. \\
\hline Patient 2 & x & x & x & x & x & x & x \\
\hline Patient 3 & x & x & x & x & x & x & x \\
\hline Patient 4 & x & x & x & x & x & x & x \\
\hline Patient 5 & x & x & x & x & x & x & x \\
\hline Patient 6 & x & x & x & x & x & x & x \\
\hline
\end{tabular}


Table 3b. Overview of samples for CEP 7/10 and CEP X/Y FISH or subtelomere FISH analyses of chondrocyte spheroid cultures.

\begin{tabular}{|l|c|c|c|c|c|c|c|c|c|c|c|c|c|c|c|}
\hline Passage & \multicolumn{3}{|c|}{ P 2 } & \multicolumn{3}{c|}{ P 3 } & \multicolumn{3}{c|}{ P 4 } & \multicolumn{3}{c|}{ P 5 } & \multicolumn{3}{c|}{ P 10} \\
\hline Weeks & 2 & 3 & 6 & 2 & 3 & 6 & 2 & 3 & 6 & 2 & 3 & 6 & 2 & 3 & 6 \\
\hline Patient 1 & x & x & x & x & x & x & x & x & x & x & x & x & x & x & 7 weeks \\
\hline Patient 2 & x & x & x & x & x & x & x & x & x & x & x & x & x & x & x \\
\hline Patient 3 & x & x & x & x & x & x & x & x & x & x & x & x & x & x & x \\
\hline Patient 4 & x & x & x & x & x & x & x & x & x & x & x & x & x & x & x \\
\hline Patient 5 & x & x & x & x & x & x & x & x & x & x & x & x & x & x & x \\
\hline Patient 6 & x & x & x & x & x & x & x & x & x & x & x & x & x & x & 5 weeks \\
\hline
\end{tabular}

Table 3c. Overview of samples for SNP array analysis of chondrocyte spheroid cultures.

\begin{tabular}{|c|c|c|c|c|c|c|c|c|c|c|c|c|c|c|c|}
\hline Passage & & $\mathbf{P} 2$ & & & $\mathbf{P} 3$ & & & $\mathbf{P} 4$ & & & P 5 & & & & 10 \\
\hline Weeks & 2 & 3 & 6 & 2 & 3 & 6 & 2 & 3 & 6 & 2 & 3 & 6 & 2 & 3 & 6 \\
\hline \begin{tabular}{|l|} 
Patient 1 \\
\end{tabular} & & & $x$ & & & & & & $x$ & & & & & & 7 weeks \\
\hline Patient 2 & & & $x$ & & & & & & $x$ & & & & & & $x$ \\
\hline Patient 3 & & & $x$ & & & & & & $x$ & & & & & & $x$ \\
\hline \begin{tabular}{|l|} 
Patient 4 \\
\end{tabular} & & & $x$ & & & & & & $x$ & & & & & & $x$ \\
\hline Patient 5 & & & $x$ & & & & & & $x$ & & & & & & $x$ \\
\hline Patient 6 & & & $x$ & & & & & & $x$ & & & & & & 5 weeks \\
\hline
\end{tabular}
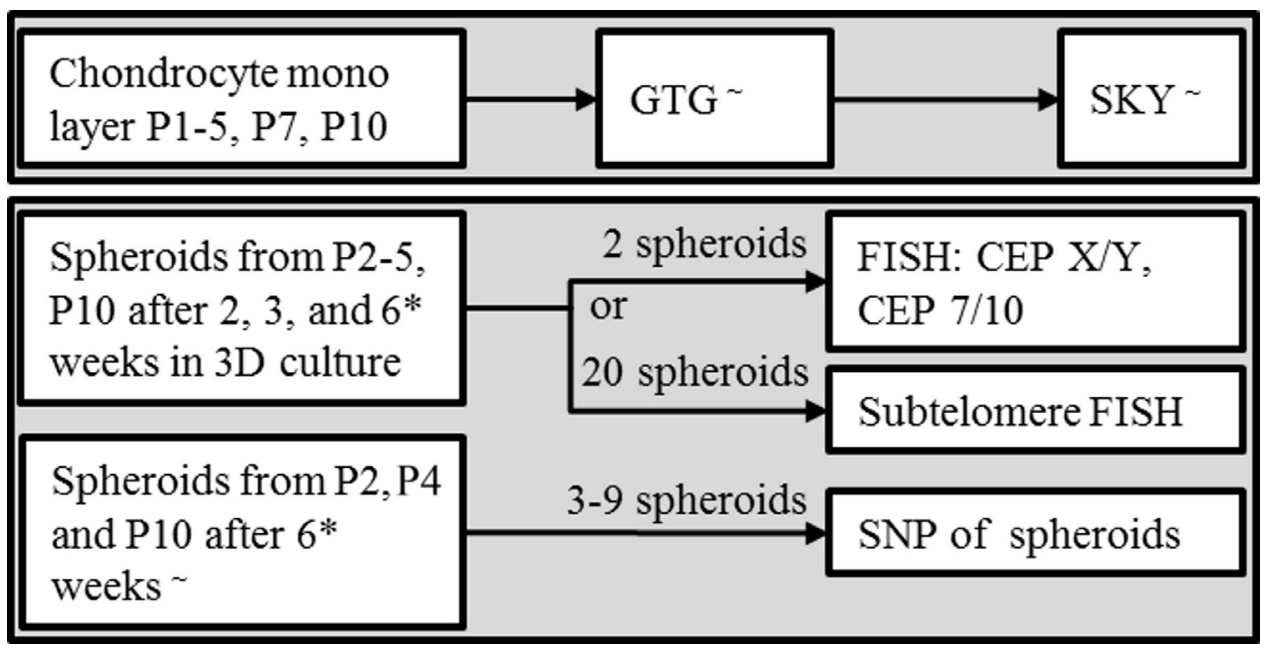

Fig. 2. Overview of the applied cytogenetic and molecular cytogenetic analyses. The differentiation phase after P 10 was 7 weeks in patient 1 and 5 weeks in patient 6 instead of the standard 6 weeks $\left(^{*}\right)$. No data were available from monolayer culture of patient 1 in P 1 and P $10(\sim)$.

\section{Chromosome preparation, GTG-banding, SKY and FISH analyses}

According to the study design (Fig. 1, Tables $3 \mathbf{a}, \mathbf{b})$, chromosome preparation was performed on chondrocyte monolayer cells of multiple passages using standard cytogenetic techniques (colcemid treatment, hypotonic treatment and methanol/ acetic acid fixation), GTG and SKY, according to manufacturer's instructions (ASI, EdingenNeckarhausen, Baden-Württemberg, Germany) for karyotype analyses on chromosome spreads. The chondrocyte monolayer cultures were analysed by
GTG-banding of 6-50 (mainly 25) MC per sample from two independent culture flasks. Additionally, 5-23 (mainly 10) metaphases were analysed by SKY (excluding patient 4, P 10 and patient 6, P 7) from one culture flask. For SKY analyses SKY-Paint DNA-H10 probes (ASI, Edingen-Neckarhausen, Baden-Württemberg, Germany) were used.

Chondrocyte spheroid samples, generated from different passages and three durations of the terminal differentiation phase of 2, 3 and 6 weeks, were analysed. If two spheroids were available, FISH analyses using the centromeric probes CEP X/Y 


\section{Monolayer - polyploid MC}

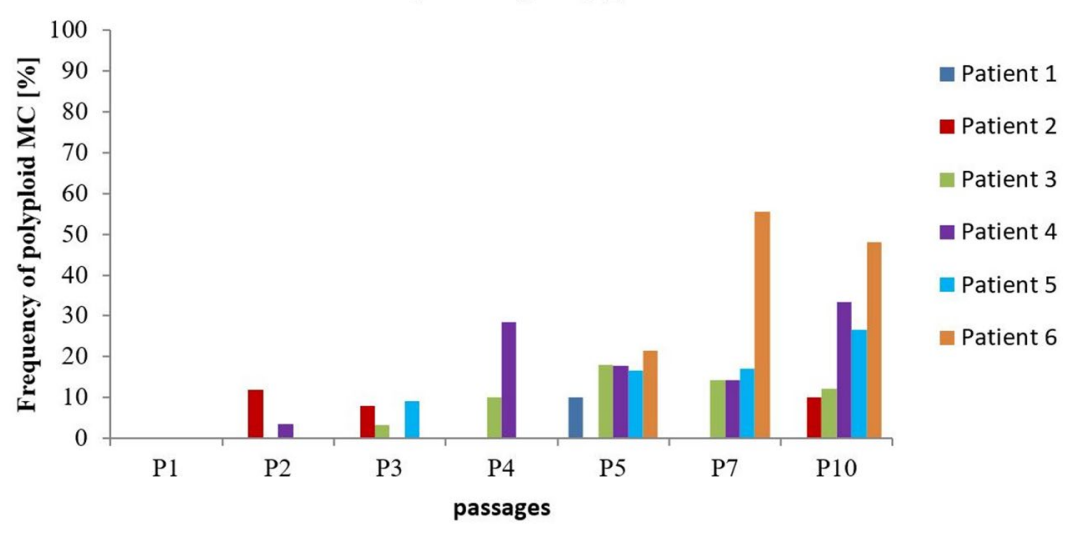

Fig. 3. Relative occurrence of polyploid MC with increasing cultivation time in monolayer cultures of 6 patients. Patterned columns indicate the frequency of polyploid MC from one culture batch, whereby these aberrations could not be confirmed in the parallel second culture batch. Completely stained columns depict the frequency of the sum of polyploid MC from both culture batches. Analyses were performed using GTG-banding according to ISCN guidelines (McGowan-Jordan et al., 2016; Shaffer, 2013). No data were available from monolayer culture of patient 1 in P 1 and P 10.

(spectrum orange/green; Abbott, Wiesbaden, Hesse, Germany) and CEP 7/10 (spectrum green/orange; Abbott) were performed.

Subtelomere FISH (ToTelVysion Multi-colour DNA probe mixtures; Abbott) analysis was performed if 20 spheroids were available (Fig. 2). In total, 18,511 IC were analysed using FISH CEP X/Y (10,045 IC) and CEP 7/10 (8,466 IC) and 5,424 IC were analysed using subtelomere FISH. To exclude artefacts in the detection of gonosome aberration, a gonosomal chromosome loss was counted only if the other gonosome was detected.

\section{DNA isolation and molecular karyotyping using SNP array}

Depending on the availability, 3-9 chondrocyte spheroids of the 6 weeks differentiation group from 5 out of 6 patients (except patient 4) of P 2, P 4 and P 10 (Table $3 \mathbf{c}$ ) were collected and subjected to genome-wide $\mathrm{CNV}$ analysis and assessment of copy number neutral loss of heterozygosity (cn-LOH) of chromosomal regions using SNP array (Affymetrix CytoScan ${ }^{\circledR} 750$ Array; ATLAS Biolabs, Berlin, Berlin, Germany). Genomic DNA was extracted from chondrocyte spheroid samples according to the protocol "Isolation of total DNA from tissues" from the QIAamp ${ }^{\circledR}$ DNA Investigator Kit (QIAGEN). DNA quality was checked by agarose gel electrophoresis. For SNP array analyses, the Affymetrix Chromosome Analysis Suite (ChAS 2.0.0.195) vs. reference data file Affymetrix CytoScan750_Array.na32.3.v. using the copy number and $\mathrm{LOH}$ workflows with standard settings was used.

\section{Results}

The genetic analyses performed revealed no significant genetic instability in 3 monolayer culture passages, as well as IC from spheroid cultures differentiated for 2, 3 and 6 weeks within P 1-3.

\section{Cytogenetics \\ Monolayer}

Chondrocyte monolayer cultures from 6 patients in different passages, including P 1 (except patient 1 ), P 2 to P 5, P 7 and P 10 (except patient 1), were analysed cytogenetically using GTG-banding. In total, 1,233 MC were analysed by GTG-banding, of which $84 \mathrm{MC}$ $(6.8 \%)$ showed clonal aberrations. Additionally, 393 MC were analysed by SKY (excluding patient 4, P 10 and patient 6, P 7). Using SKY on monolayer cultures, no additional recurrent chromosomal aberrations were identified.

All monolayer samples showed predominantly normal karyotypes, as seen by GTG-banding and SKY (patient 1: 46,XX; patient 2: 46,XY; patient 3: 46,XY; patient 4: 46,XX; patient 5: $46, X X$; patient $6: 46, X X)$, with no indication of clonal aberrations until P 3 . In addition to these predominantly inconspicuous cell populations, cell populations with polyploid MC from two cultures were present at a lower frequency, as measured by GTG-banding. Clonal occurrence of polyploid MC ( $\geq 10 \%)$ was found in patients 3 and 4 from $\mathrm{P} 4$ and in patients 5 and 6 from P 5 onwards. Furthermore, clonal occurrence of polyploid MC, larger than $10 \%$, was detected in the remaining three patient samples, with patient 1 at $\mathrm{P} 5$ and patient 2 at P 10 (Fig. 3). In summary, a tendency towards the occurrence of polyploid chondrocyte cell populations over prolonged monolayer cultivation accompanied by higher passage levels was observed.

Monolayer cells of patient 2 and 3 (from two cultures) showed an increase in endoreduplications with increasing cultivation time from P 4 onwards (Fig. 4). Moreover, two endoreduplications of one cultivation batch were found in P 5 monolayer cells of patient 5. Interestingly, in monolayer cells of 


\section{Monolayer - endoreduplications}

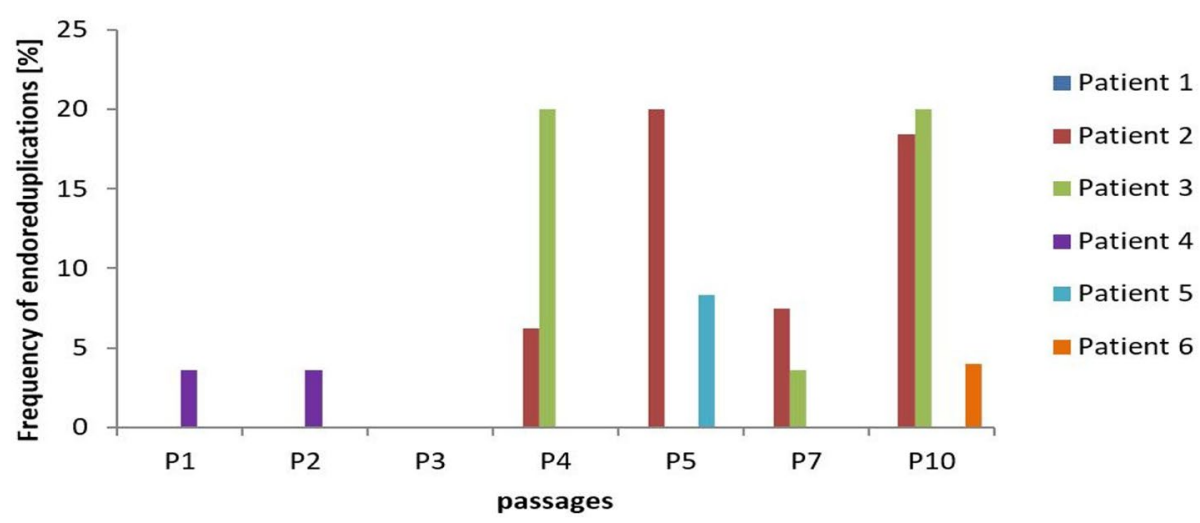

Fig. 4. Relative occurrence of endoreduplications with increasing cultivation time in monolayer cultures of six patients. Patterned columns indicate the frequency of endoreduplications from one culture batch, whereby these aberrations could not be confirmed in the parallel second culture batch. Completely stained columns depict the frequency of the sum of endoreduplications from both culture batches. In patient 1 , no endoreduplications were detected throughout the entire monolayer cultures. Analyses were performed using GTG-banding according to ISCN guidelines (McGowan-Jordan et al., 2016; Shaffer, 2013). No data were available from monolayer culture of patient 1 in P 1 and P 10.

Table 4. Numerical and structural chromosomal aberrations detected by GTG and/or SKY in monolayers of patient 2 .

\begin{tabular}{|c|c|c|c|}
\hline Passage & Aberration & $\begin{array}{c}\text { Aberrant } \\
\text { metaphases }\end{array}$ & $\begin{array}{c}\text { Total } \\
\text { metaphases }\end{array}$ \\
\hline 1 & $\begin{array}{l}\text { Trisomy of the chromosome } 7 \\
\text { Deletion of the chromosome 10: } \operatorname{del}(10)(q 25)\end{array}$ & $\begin{array}{l}1 \\
1\end{array}$ & $\begin{array}{l}44 \\
44\end{array}$ \\
\hline 2 & $\begin{array}{l}\text { Polyploid metaphases } \\
\text { Trisomy of the chromosome } 7 \\
\text { Y chromosomal loss }\end{array}$ & $\begin{array}{l}3 \\
1 \\
2\end{array}$ & $\begin{array}{l}35 \\
35 \\
35\end{array}$ \\
\hline 3 & Trisomy of chromosomes 7 and 12 & 1 & 39 \\
\hline 4 & $\begin{array}{l}\text { Trisomy of the chromosome } 7 \\
\text { Y chromosomal loss } \\
\text { Deletion of the chromosome 16: } \operatorname{del}(16)(q 12)\end{array}$ & $\begin{array}{l}1 \\
1 \\
1\end{array}$ & $\begin{array}{l}42 \\
42 \\
42\end{array}$ \\
\hline 5 & $\begin{array}{l}\text { Trisomy of the chromosomes } 5,6,7,8,9 \text {, and } 10 \\
\text { Translocation of the chromosome } 9 \\
\text { [der(9)t(9;?)(?;?)] } \\
\text { Translocation of the chromosomes } 7,9 \text { and } 12[\mathrm{t}(7 ; 9 ; 12) \\
(\mathrm{q} 11.2 ; q 34 ; q 24)]\end{array}$ & $\begin{array}{l}1 \\
1 \\
1\end{array}$ & $\begin{array}{l}30 \\
30 \\
30\end{array}$ \\
\hline 7 & $\begin{array}{l}\text { Y chromosomal loss } \\
\text { Monosomy of the chromosome } 22 \\
\text { Trisomy of the chromosome } 7 \\
\text { Translocation }[\mathrm{t}(10 ; 11)(\mathrm{q} 10 ; \mathrm{q} 10)] \\
\text { Marker chromosome }\end{array}$ & $\begin{array}{l}4 \\
3 \\
2 \\
1 \\
1\end{array}$ & $\begin{array}{l}40 \\
40 \\
40 \\
40 \\
40\end{array}$ \\
\hline 10 & $\begin{array}{l}\text { Polyploid metaphases } \\
\text { Trisomy of the chromosome } 1 \\
\text { Trisomy of the chromosome } 7 \\
\text { Trisomy of the chromosome } 8 \\
\text { Trisomy of the chromosome } 13 \\
\text { Tetrasomy of the chromosome } 7 \\
\text { Deletion of the X chromosome }[\operatorname{del}(X)(q ?)] \\
\text { Translocation of the chromosomes } 22 \text { and } 21[t(22 ; 21)(? ; ?)]\end{array}$ & $\begin{array}{l}5 \\
1 \\
4 \\
3 \\
1 \\
1 \\
1 \\
1\end{array}$ & $\begin{array}{l}65 \\
65 \\
65 \\
65 \\
65 \\
65 \\
65 \\
65\end{array}$ \\
\hline
\end{tabular}




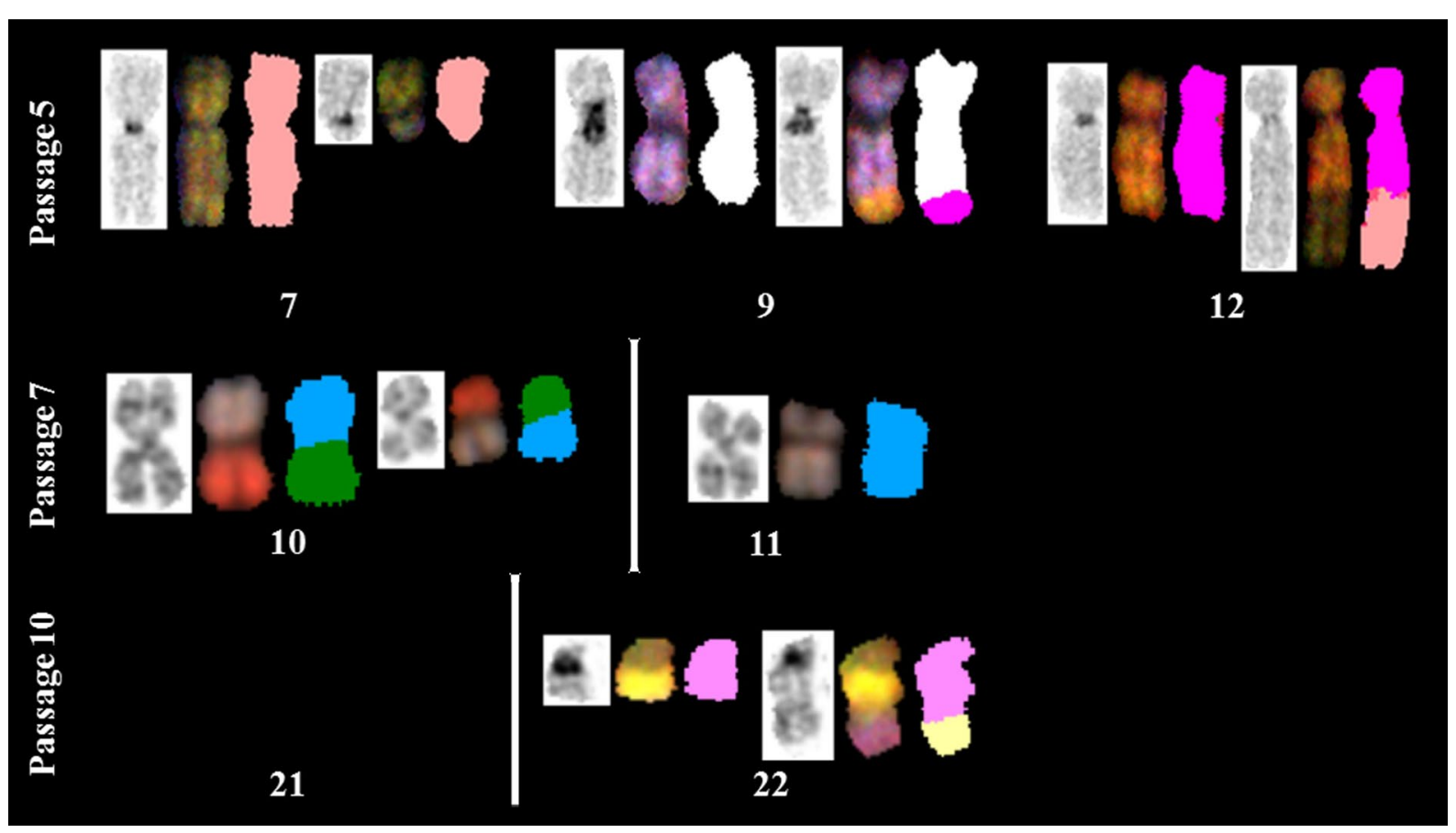

Fig. 5. Examples of detected structural aberrations using SKY technique. $\mathrm{t}(7 ; 9 ; 12)(\mathrm{q} 11.2 ; \mathrm{q} 34 ; \mathrm{q} 24)$, $\mathrm{P}$ 5; chromosomes 10 and 11 [t(10;11)(q10; q10)], P 7; chromosomes 21 and 22 [t(22;21)(?;?)], P 10 were found in different MC monolayer cultures of patient 2.

patient 2, indications of chromosomal instability were identified using both GTG-banding and SKY. As summarised in Table 4, numerical and structural aberrations were detected as single events from $\mathrm{P} 1$ to P 5, but in P 7 and P 10, the following numerical chromosomal aberrations were found as clonal events: Y chromosome loss, monosomy 22, trisomy 7 and 8 and polyploid MC.

The SKY technique revealed the following structural chromosomal aberrations as single events: $\operatorname{del}(10)(q 25)$ in $P 1, \operatorname{del}(16)(q 12)$ in $P$, $[\operatorname{der}(9) t(9 ; ?)$ (?:?)] and [t(7;9;12)(q11.2;q34;q24)] in P 5, t(10;11) $(q 10 ; 10)$ and one marker chromosome in $\mathrm{P} 7, \operatorname{del}(X)$ (q?) and t(22;21)(?;?) in P 10 (Fig. 5), which is partially described for EMC by Sjögren et al. (2003). Gonosomal losses were detected in patient 2 at P 2 (2/10 SKYmetaphases, from one cultivation batch) and at $\mathrm{P} 7$ (4/25 GTG-metaphases, from one cultivation batch).

\section{Spheroids}

In parallel, 18,511 IC from 3D spheroid cultures were analysed using FISH with centromere probes CEP X/Y and CEP 7/10. In total, an average of 124 IC (20-356 IC; using CEP X/Y) and 105 IC (16-362 IC; using CEP 7/10) were detected (Table 5). 10,045 IC were available for FISH probe CEP X/Y. 167/10,045 IC ( $1.67 \%$ ) showed aberrant single signal patterns $\geq 10 \%$ (51 IC with loss of one signal for the chromosome $X, 116$ IC with loss of the signal for chromosome Y). $X$ chromosomal losses of more than $10 \%$ in three spheroid differentiation phases were detected for the first time in P 10: 2 weeks; P 10: 3 weeks; P 10: 5 weeks, only in patient 6 . In patient 2 , significant $\mathrm{Y}$ chromosomal losses in spheroid cultures from
P 4 onwards were identified, which increased over prolonged 3D cultivation [P 4: 6 weeks; P 5: 3 and 6 weeks; P 10: 2 (subteleromeric FISH), 3 and 6 weeks; Table 6a]. 8,466 IC were available for FISH probe CEP 7/10. 63/8,466 IC (0.74\%) showed aberrant single signal patterns $\geq 10 \%$ [61 IC with three signals for chromosomes 7 and 10, respectively (patient 2, P 10: 3 weeks; patient 6, P 10: 2, 3 and 7 weeks, possible suggestions for polyploidy), and 2 IC with only one signal for chromosome 7 and two signals for chromosome 10 (patient 1, P 5: 2 weeks; 2/16 IC: limited appreciation)] (Table 6b). When 20 spheroids were available, subtelomere FISH analysis was performed instead of CEP FISH analysis (Fig. 2). The analysis of 5,424 IC revealed that 95 IC (1.75\%) were involved in aberrant single signal patterns $\geq 10 \%$ [three signals for $4 p, 7 p / q, 9 p, 14 q, 20 p$; four signals for $16 p / q, 19 p / q$; one signal for $13 q, 17 q, 18 p$, gonosomes (Table 6c)].

\section{SNP array}

SNP array analysis did not detect any CNV in all of the chondrocyte spheroids produced from P 2 and P 4 monolayer cells for the five analysed patients (chondrocyte spheroid sample from patient 4 was not analysed by SNP array) (Table 7). Furthermore, no abnormality was detectable in any spheroid group produced from P 10 monolayer cells of patients 1, 3 and 5 . However, CNVs were identified in 5 (patient 6) and 6 (patient 2) week-old chondrocyte spheroids generated from P 10 monolayer cells of two patients. While cells of patient 2 showed gain of complete chromosomes 7 and 10, cells of patient 6 showed gain of complete chromosome 8 accompanied by clonal 
Table 5. Mean values of analysed IC (FISH) generated from various $\mathrm{P}$ and differentiation phases. FISH using CEP X/Y and CEP 7/10.

\begin{tabular}{|c|c|c|}
\hline \multirow{2}{*}{ Patient } & \multicolumn{2}{|l|}{$\begin{array}{l}\text { Mean value of analysed interphase } \\
\text { cells [range values] }\end{array}$} \\
\cline { 2 - 3 } & CEP X/Y & CEP 7/10 \\
\hline 1 & $101[42-184]$ & $68[16-172]$ \\
\hline 2 & $188[86-356]$ & $157[78-362]$ \\
\hline 3 & $162[54-239]$ & $134[51-225]$ \\
\hline 4 & $102[20-137]$ & $88[24-131]$ \\
\hline 5 & $86[54-116]$ & $83[41-124]$ \\
\hline 6 & $104[60-177]$ & $97[58-137]$ \\
\hline
\end{tabular}

loss of one complete $\mathrm{X}$ chromosome. Additionally, an indication of gain of chromosomal material was detectable for chromosomes 7 and 10 of $\mathrm{P} 10$ in the 5 week-old spheroids of patient 6 (Table 7).

cn-LOH regions were detected in all spheroid variants of four out of five analysed donors, independently of the underlying monolayer passage levels (Table 8 ). The largest cn- $\mathrm{LOH}$ region with a size of $>7 \mathrm{Mbp}$ was revealed in patient 5 at P 2, P 4 and $\mathrm{P} 10$ at the chromosomal region Xq13.1-q21.1. A cn- $\mathrm{LOH}$ region of $>5 \mathrm{Mbp}$ was detected at the chromosomal region 11p11.2-11.12 and 11q14.1 of patient 1 at P 2, P 4 and P 10 (Fig. 6). Germline material, such as peripheral blood of patients, was not available. SNP array analyses of patient 2 showed two cn-LOH regions ( $>3 \mathrm{Mbp}$ ), one localised at 11p11.2-p11.12 and the other at 15q15.1-q21.1. In patient 6, SNP array analyses showed a $\mathrm{cn}-\mathrm{LOH}$ region (>3 Mbp) at 16p11.2-p11.1 (Table 8).

\section{Discussion}

Genetic stability is important in cell-based therapies due to a variety of (clonal) numerical and/or structural aberrations that may occur in genetically instable or altered cells. Therefore, a not previously described comprehensive genetic analysis of six chondrocyte donors was performed [using GTG-banding, SKY, FISH and genome wide SNP array $(n=5)]$ to evaluate the genetic stability of these chondrocyte cultures, processed in close analogy to the current GMP production of Spherox ${ }^{\circledR}$ - which is intended as ACT treatment.

\section{Autosomal chromosomes}

Cytogenetic and molecular profiling of 2D and 3D chondrocyte cultures by GTG-banding, SKY, (centromeric or subtelomere) FISH and SNP array did not give clear indications of chromosomal instability during cultivation up to $\mathrm{P} 3$. With prolonged cultivation times, chromosomal aberrations occurred, partially also clonally present (e.g. polyploidy). According to the manufacturer of the ATMPcandidate Spherox ${ }^{\circledR}$, co.don ${ }^{\circledR} A G$, this prolonged 2D cultivation time is not included in the production process of Spherox ${ }^{\circledR}$. Preferably, chondrocytes of P 2 are used to generate spheroids.

Cytogenetic and/or molecular cytogenetic publications on chondrocyte cultures are limited. Trimborn et al. (2012), analysing seven $12-48 \mathrm{~h}$ postmortem human donors (22 to 62 year-old), report high frequency of aneuploidies (up to $26.7 \%$ ) by GTG-banding and gains and losses of gonosomes and gains of chromosomes 5, 7 and 8 (up to $10 \%$ ). These aberrations are already present in $\mathrm{P} 1$, suggesting the occurrence in the harvested full-depth cartilage biopsy. However, five samples from younger patients (22 to 40 year-old and scheduled for ACI), without signs of osteoarthritic degeneration or traumatic injury, show mainly unremarkable karyotypes. Only single events of numerical and structural chromosomal aberrations are described. Williams et al. (2010), in a study on expanded full-depth normal human chondrocytes isolated from three patients undergoing knee surgery, show unremarkable karyotypes. Fuente et al. (2004) measure no effect on chromosomal stability after prolonged expansion time of expanded dedifferentiated adult human cartilage chondrocytes, karyotyping 3 cell samples from 25 donors (16 to 54 year-old) from 10 and 20

Table 6a. Single aberrant signal pattern during differentiation phase in spheroid cultures using CEP X/Y. Aberrant signal patterns $\geq 10 \%$ are presented.

\begin{tabular}{|c|c|c|c|c|c|}
\hline Patient & $\begin{array}{c}\text { Differentiation } \\
\text { phase }\end{array}$ & Aberrant IC & Analysed IC & $\begin{array}{c}\text { Frequency of } \\
\text { aberrant signal }\end{array}$ & Aberrant signal pattern \\
\hline 2 & P 4, 6 weeks & 15 & 135 & $11.11 \%$ & $\mathrm{X}: \mathrm{x} 1 ; \mathrm{Y}: \mathrm{x} 0$ \\
\hline 2 & $\mathrm{P} 5,3$ weeks & 28 & 235 & $11.91 \%$ & $\mathrm{X}: \mathrm{x} 1 ; \mathrm{Y}: \mathrm{x} 0$ \\
\hline 2 & P 5, 6 weeks & 16 & 110 & $14.55 \%$ & $\mathrm{X}: \mathrm{x} 1 ; \mathrm{Y}: \mathrm{x} 0$ \\
\hline 2 & P 10, 3 weeks & 41 & 187 & $21.93 \%$ & $\mathrm{X}: \mathrm{x} 1 ; \mathrm{Y}: \mathrm{x} 0$ \\
\hline 2 & P10, 6 weeks & 16 & 135 & $11.85 \%$ & $\mathrm{X}: \mathrm{x} 1 ; \mathrm{Y}: \mathrm{x} 0$ \\
\hline 6 & P 10, 2 weeks & 30 & 77 & $38.96 \%$ & $\mathrm{X}: \mathrm{x} 1$ \\
\hline 6 & P 10,3 weeks & 11 & 78 & $14.10 \%$ & $\mathrm{X}: \mathrm{x} 1$ \\
\hline 6 & P 10,7 weeks & 10 & 88 & $11.36 \%$ & $\mathrm{X}: \mathrm{x} 1$ \\
\hline
\end{tabular}


Table 6b. Single aberrant signal pattern during differentiation phase in spheroid cultures using CEP 7/10. Aberrant signal patterns $\geq 10 \%$ are presented.

\begin{tabular}{|c|c|c|c|c|c|}
\hline Patient & $\begin{array}{c}\text { Differentiation } \\
\text { phase }\end{array}$ & Aberrant IC & Analysed IC & $\begin{array}{c}\text { Frequency of } \\
\text { aberrant signal }\end{array}$ & Aberrant signal pattern \\
\hline 1 & P 5, 2 weeks & 2 & 16 & $12.50 \%$ & $7: \times 1 ; 10: \times 2$ \\
\hline 2 & P 10, 3 weeks & 13 & 116 & $11.21 \%$ & $7: \times 3 ; 10: \times 3$ \\
\hline 6 & P 10, 2 weeks & 22 & 137 & $16.06 \%$ & $7: \times 3 ; 10: \times 3$ \\
\hline 6 & P 10, 3 weeks & 17 & 99 & $17.17 \%$ & $7: \times 3 ; 10: \times 3$ \\
\hline 6 & P 10, 7 weeks & 9 & 58 & $15.52 \%$ & $7: \times 3 ; 10: \times 3$ \\
\hline
\end{tabular}

Table 6c. Single aberrant signal pattern during differentiation phase in spheroid cultures using subtelomere FISH. Aberrant signal patterns $\geq 10 \%$ are presented.

\begin{tabular}{|c|c|c|c|c|c|}
\hline Patient & \begin{tabular}{|c|}
$\begin{array}{c}\text { Differentiation } \\
\text { phase }\end{array}$ \\
\end{tabular} & Aberrant IC & Analysed IC & $\begin{array}{c}\text { Frequency of } \\
\text { aberrant signal }\end{array}$ & Aberrant signal pattern \\
\hline 2 & P 3, 2 weeks & 5 & 50 & $10.00 \%$ & $7 \mathrm{p} / \mathrm{q}: \mathrm{x} 2 ; 14 \mathrm{q}: \mathrm{x3}$ \\
\hline 2 & P 10, 2 weeks & 6 & 57 & $10.53 \%$ & 1p/q: x2; Xp/Yp: x1 \\
\hline 2 & P 10, 2 weeks & 6 & 51 & $11.76 \%$ & 4p: x3; 4q: x2; 21q: x2 \\
\hline 2 & P 10, 2 weeks & 6 & 53 & $11.32 \%$ & $6 \mathrm{p} / \mathrm{q}: \times 2 ; 13 \mathrm{q}: \times 1$ \\
\hline 2 & P 10, 2 weeks & 8 & 51 & $15.69 \%$ & 7p/7q: x3; 14q: x2 \\
\hline 2 & P 10, 2 weeks & 7 & 54 & $12.96 \%$ & 9p: x3; 9q: x2; 17q: x2 \\
\hline 2 & P 10, 2 weeks & 6 & 50 & $12.00 \%$ & 12p: x1; 12q: x2; 18q: x2 \\
\hline 2 & P 10, 2 weeks & 6 & 53 & $11.32 \%$ & $16 \mathrm{p} / \mathrm{q}: \mathrm{x} 4$ \\
\hline 2 & P 10, 2 weeks & 8 & 50 & $16.00 \%$ & 20p: x3; 20q: x2 \\
\hline 3 & P 10, 2 weeks & 8 & 50 & $16.00 \%$ & 2p/q: x2; Xq/Yq: x1 \\
\hline 3 & P 10, 2 weeks & 6 & 51 & $11.76 \%$ & 6p/q: x2; 13q: x1 \\
\hline 3 & P 10, 2 weeks & 7 & 50 & $14.00 \%$ & 9p/q: x2, 17q: x1 \\
\hline 3 & P 10, 2 weeks & 6 & 54 & $11.11 \%$ & 11p/q: x2, 18p: x1 \\
\hline 3 & P 10, 2 weeks & 5 & 50 & $10.00 \%$ & 19p: x4, 19q: x2 \\
\hline 3 & P 10, 2 weeks & 5 & 50 & $10.00 \%$ & 19p/q: $x 4$ \\
\hline
\end{tabular}

PDLs. Finally, Stumm et al. (2012), using human chondrocytes (articular cartilage tissue from patients with total knee replacement surgery and healthy cartilage from human organ donors) reveal autosomal stability, but losses of $Y$ chromosomes.

Interestingly, in the current study, for patient 2, numeric and structural aberrations were detected as single events in all early passage levels from P 1 to P 5. In P 7 and P 10, the following chromosomal changes were present as clonal events: loss of $Y$ chromosome, monosomy 22, trisomy 7 and 8 and polyploid MC. Further chromosomal aberrations, such as trisomy of chromosome 12 and involvement in translocations of chromosomes 7 and 9 (described for EMC) were also observed. Based on the presence of (initial) single aberrations already in P 1 , it cannot be excluded that the harvested cells (from cartilage biopsy of an osteoarthritic knee) already carried these chromosomal aberrations. Thus, future stability studies should also investigate the properties of the starting material or, more specifically, the freshly isolated primary chondrocytes in addition to peripheral lymphocytes of whole blood samples, to discriminate whether the observed genetic alterations are due to the cultivation process or are inherent to the material itself. Usually, such autosomal chromosomal aberrations can be found in cartilaginous tumours. Cytogenetics in 21 benign chondromatous tumours show chromosomal aberration on chromosomes 5, 6, 7 and 12. The chromosomal regions 6q13, 12q13 and 17p13 are detectable in both malignant and benign cartilaginous tumours (Buddingh et al., 2003). Noteworthy are the following chromosomal aberrations that were detected in different differentiation phases of monolayer cells of donor 2: deletion of chromosome 6 , trisomy of chromosomes 1,7 and 8 , translocations der(9)t(9;?)(?;?) and $\mathrm{t}(7 ; 9 ; 12)(\mathrm{q} 11.2 ; \mathrm{q} 34 ; \mathrm{q} 24)$. Similar chromosomal aberrations are described in connection with EMC [e.g. $\mathrm{t}(9 ; 15)(\mathrm{q} 22 ; \mathrm{q} 21), \mathrm{t}(9 ; 17)(\mathrm{q} 22 ; \mathrm{q} 11-12)$, 


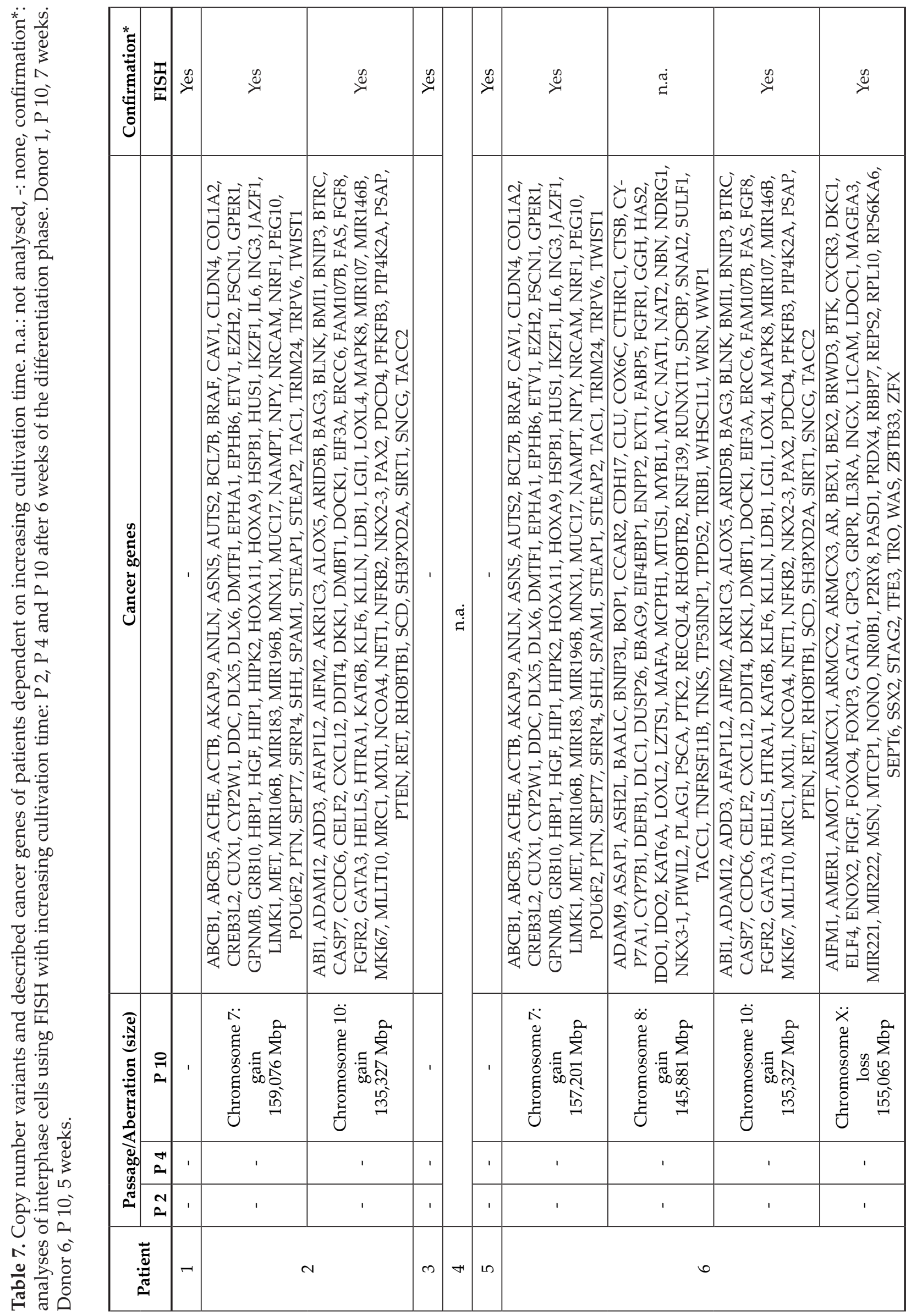


$\mathrm{t}(9 ; 22)(\mathrm{q} 22 ; \mathrm{q} 12)$ and $\mathrm{t}(7 ; 9 ; 17)(\mathrm{q32} ; \mathrm{q} 22 ; \mathrm{q11})]$ (Sjögren et al., 2003). Translocation $\mathrm{t}(9 ; 22)(\mathrm{q} 22 ; \mathrm{q} 12)$ is a characteristic recurrent translocation in EMC, which is present in approximately in $75 \%$ of the patients. An additional variant $\mathrm{t}(9 ; 17)(\mathrm{q} 22 ; \mathrm{q} 11)$ is documented in approximately in $15 \%$ of cases. Additional variants with $\mathrm{t}(9 ; 15)(\mathrm{q} 22 ; \mathrm{q} 21)$ and $\mathrm{t}(3 ; 9)(\mathrm{q} 12 ; \mathrm{q} 22)$ are also described. Also, in approximately $50 \%$ of EMC, trisomies of chromosome 1 (partial trisomy), 7, 8, 12 and 19 are identified (Nishio et al., 2011). Although the biological significance of these chromosomal aberrations is not yet fully known, a correlation between increase of aneuploidy and the progression of EMC from low to high WHO grades is observed (Hameed et al., 2009). Other chondrosarcomas show polysomy 8 (Morrison et al., 2005) or losses in chromosomes 5q, 6q and 9p (Hameed et al., 2009).

\section{Gonosomal chromosomes}

$X$ chromosomal losses of $\geq 10 \%$ in spheroids first occurred from $\mathrm{P} 10$ and only in patient 6, which is, according to co.don ${ }^{\circledR} \mathrm{AG}$, outside of the standard

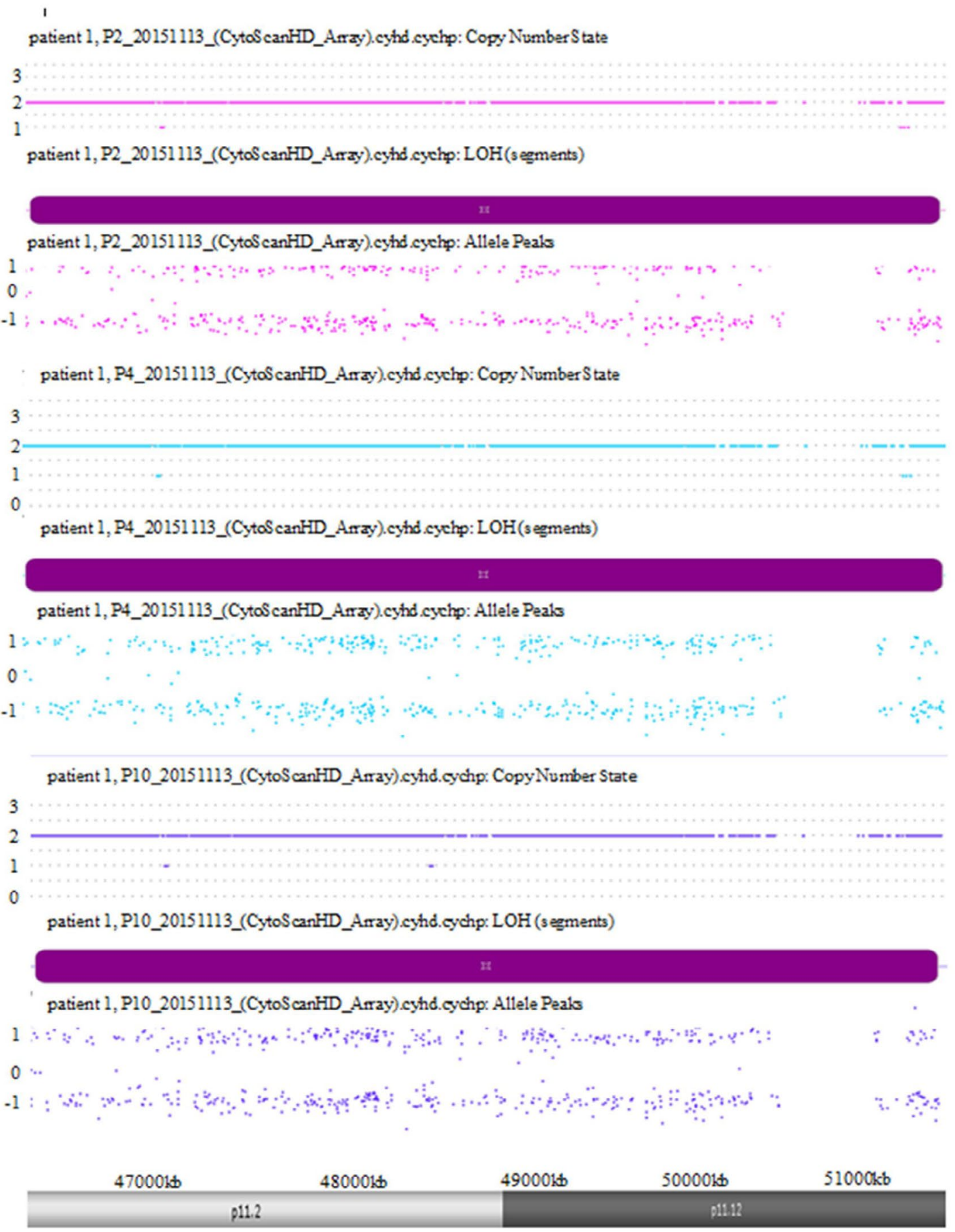

Fig. 6. Example of cn-LOH detection using SNP array analysis. Three different spheroid cultures (P 2, P 4 and $\mathrm{P} 10$ ) of patient 1 in the $\mathrm{cn}-\mathrm{LOH}$ region (violet bars) of 11p11.2-p11.12 (5,259 Mbp, physical position: $46,304,337-51,563,636)$ are presented using SNP array. P 2 is shown in red, P 4 in light blue and P 10 in dark blue. 
Table 8. Chromosomal regions (cn-LOH) and described cancer genes dependent on increasing cultivation time. Increasing cultivation time P 2, P 4, and P 10 after 6 weeks of the differentiation phase. Patient 1, P 10, 7 weeks and patient 6, P 10, 5 weeks.

\begin{tabular}{|c|c|c|c|c|c|}
\hline \multirow[b]{2}{*}{ Patient } & \multirow{2}{*}{$\begin{array}{c}\text { Affected } \\
\text { chromosomal } \\
\text { area }\end{array}$} & \multicolumn{3}{|c|}{ Passage/size/physical position } & \multirow[t]{2}{*}{$\begin{array}{l}\text { Cancer } \\
\text { genes }\end{array}$} \\
\hline & & $\mathbf{P} 2$ & $\mathbf{P} 4$ & $\mathbf{P} 10$ & \\
\hline \multirow{2}{*}{1} & $\begin{array}{l}\text { Chromosome } \\
\text { 11p11.2-p11.12 }\end{array}$ & $\begin{array}{c}5,259 \mathrm{Mbp} \\
46,304,337-51,563,636 \mathrm{Mbp}\end{array}$ & $\begin{array}{c}5,259 \mathrm{Mbp} \\
46,304,337-51,563,636 \mathrm{Mbp}\end{array}$ & $\begin{array}{c}5,259 \mathrm{Mbp} \\
46,304,337-51,563,636 \mathrm{Mbp}\end{array}$ & $\begin{array}{l}\text { DDB2, } \\
\text { PTPRJ }\end{array}$ \\
\hline & $\begin{array}{c}\text { Chromosome } \\
11 \text { 14.1 }\end{array}$ & $\begin{array}{c}3,154 \mathrm{Mbp} \\
81,224,285-84,377,856 \mathrm{Mbp}\end{array}$ & $\begin{array}{c}3,154 \mathrm{Mbp} \\
81,224,285-84,377,856 \mathrm{Mbp}\end{array}$ & $\begin{array}{c}3,148 \mathrm{Mbp} \\
81,229,936-84,377,856 \mathrm{Mbp}\end{array}$ & \\
\hline \multirow{2}{*}{2} & $\begin{array}{c}\text { Chromosome } \\
\text { 11p11.2-p11.12 }\end{array}$ & $\begin{array}{c}3,623 \mathrm{Mbp} \\
47,940,924-51,563,636 \mathrm{Mbp}\end{array}$ & $\begin{array}{c}3,623 \mathrm{Mbp} \\
47,940,924-51,563,636 \mathrm{Mbp}\end{array}$ & $\begin{array}{c}1,752 \mathrm{Mbp} \\
47,933,842-49,686,065 \mathrm{Mbp}\end{array}$ & PTPRJ \\
\hline & $\begin{array}{l}\text { Chromosome } \\
15 \mathrm{q} 15.1-\mathrm{q} 21.1 \\
\end{array}$ & $\begin{array}{c}3,499 \mathrm{Mbp} \\
42,332,031-45,831,220 \mathrm{Mbp}\end{array}$ & $\begin{array}{c}3,518 \mathrm{Mbp} \\
42,332,031-45,849,655 \mathrm{Mbp}\end{array}$ & $\begin{array}{c}3,124 \mathrm{Mbp} \\
42,422,570-45,546,544 \mathrm{Mbp}\end{array}$ & \\
\hline 3 & none & - & - & - & \\
\hline 4 & \multicolumn{5}{|c|}{ n.a. } \\
\hline 5 & $\begin{array}{l}\text { Chromosome } \\
\text { Xq13.1-q21.1 }\end{array}$ & $\begin{array}{c}\text { 7,349 Mbp } \\
71,523,649-78,872,361 \mathrm{Mbp}\end{array}$ & $\begin{array}{c}7,349 \mathrm{Mbp} \\
71,523,649-78,872,361 \mathrm{Mbp}\end{array}$ & $\begin{array}{c}7,349 \mathrm{Mbp} \\
71,523,649-78,872,361 \mathrm{Mbp}\end{array}$ & \\
\hline 6 & $\begin{array}{l}\text { Chromosome } \\
16 \text { p11.2-p11.1 }\end{array}$ & $\begin{array}{c}3,328 \mathrm{Mbp} \\
31,892,235-35,220,544 \mathrm{Mbp}\end{array}$ & $\begin{array}{c}2,295 \mathrm{Mbp} \\
32,926,025-35,220,544 \mathrm{Mbp}\end{array}$ & $\begin{array}{c}2,295 \mathrm{Mbp} \\
32,926,025-35,220,544 \mathrm{Mbp}\end{array}$ & \\
\hline
\end{tabular}

production process for Spherox ${ }^{\circledR}$. Gonosomal aneuploidies are described in connection with aging processes. Russell et al. (2007) analyse 19,650 cells of 655 female donors with an age spectrum from newborn to 80 year-old subjects, measuring the frequency of $X$ chromosomal losses from $0.07 \%$ ( $\leq 16$ year-old) to $7.3 \%$ ( $\geq 65$ year-old) ( $p \leq 0.00001)$. Chapiro et al. (2014) describe a lower frequency of age-related occurrence of $X$ chromosomal losses in elderly subjects. Furthermore, these $\mathrm{X}$ chromosomal losses, including clonal losses, are detected, for example, in patients with lymphoid neoplasia (Reimann-Berg et al., 2011) and basal cell carcinomas (Kawasaki et al., 1991). Similarly, a cumulative effect of cell cultivation conditions on the occurrence of losses of $\mathrm{X}$ chromosomes cannot be ruled out at present and is described, for example, in connection with chorionic villi (Gardner et al., 2012). Results obtained for chondrocytes of patient 6 indicate such a cell cultivation effect.

The situation for $\mathrm{Y}$ chromosomal losses appears similar. Patient 2 was one of the older (73 year-old) patients in this study. Also, significant loss of the $Y$ chromosome only occurred in spheroids derived from P 4 with a PDL of just 10.41 or subsequent passages, which lies outside of the production process for Spherox ${ }^{\circledast}$. In post-mortem analyses of 7 patients, a high frequency of $\mathrm{Y}$ chromosome loss was observed in older patients (mean age of 58.1 years). However, this is not observed in younger patients (mean age of 24 years) (Trimborn et al., 2012). In addition, several studies show that loss of the $\mathrm{Y}$ chromosome occurs at a relatively high frequency in the bone marrow and peripheral blood of older patients (Pierre and Hoagland, 1972; Guttenbach et al., 1995). Results for patient 2 suggested the occurrence of this age-related and/or cell cultivation effect(s). Spontaneous loss of the $Y$ chromosome is also observed in MSCs (Nikitina et al., 2011). In contrast, loss of the $Y$ chromosome is a disease-associated chromosomal aberration in patients with haematological tumorigenesis (Wiktor et al., 2000).

In osteoarthritic tissue, using FISH analysis, Y chromosome deletions are found in $\geq 10 \%$ of the analysed IC in 6 out of 10 male patients (Castellanos et al., 2004). The lack of chromosomal aberrations in the healthy age-matched controls suggest that there is an association between chromosomal aberrations and osteoarthritis (Castellanos et al., 2004). According to Stumm et al. (2012), the observed presence or absence of the $\mathrm{Y}$ chromosome does not appear to influence the transcriptional activity of chondrocytes.

\section{Cn-LOH}

$\mathrm{Cn}-\mathrm{LOH}$ leads to $\mathrm{LOH}$ by duplication of a maternal (unimaternal) or paternal (unipaternal) chromosome or chromosomal region and concurrent loss of the other allele (O'Keefe et al., 2010). In the current work, cn-LOH > $5 \mathrm{Mbp}$ were considered as representing segmental and/or complete UPD. Using SNP array, $\mathrm{cn}-\mathrm{LOH}$ regions were detected at $11 \mathrm{p} 11.2 \mathrm{p} 11.12$ [5.26 Mbp, co.don ${ }^{\circledast}$ AG production-potential-analysis (PPA)-1: P 2, P 4 and P 10], at Xq13.1q21.1 (7.35 Mbp, patient 5: P 2, P 4 and P 10) and at 16p11.2-p11.1 (3.33 Mbp, PPA-6: P 2, P 4 and P 10). Described cancer genes within the chromosomal region 11p11.2-11p11.12 are damage-specific DNA binding protein 2 (DDB2) and receptor-type tyrosine-protein phosphatase eta (PTPRJ). DDB2 influences damage recognition prior to nucleotide excision repair (NER), since DDB proteins recognise many types of DNA lesions caused by UV damage and are inducible by treatment with DNA-damaging agents. DDB2 is involved in the protein ubiquitination pathway and in the NER pathway to initiate DNA repair together with DDB1, as UV-DDB complex (Yeh et al., 2012). PTPRJ is a member of the protein tyrosine phosphatase (PTP) family. Since its expression is increased with 
increasing cell density, it is strongly suggested that PTPRJ may contribute to the mechanism of contact inhibition of cell growth (Ostman et al., 1994). It seems to be involved in protein tyrosine kinase signalling, cell-cell signalling, vasculogenesis and heart development (Takahashi et al., 2003). PTPRJ plays a role in the $\beta$-type platelet-derived growth factor receptor (PDGFR- $\beta$ ) signalling pathway (Heldin, 2013). According to the study design of the SNP array analyses (analyses of spheroids of donors 1, 2, 3, 5, 6, P 2, P 4 and P 10), it could be excluded that the detected cn-LOHs were already present in the starting material. Therefore, they could represent constitutional events. However, it remains that most UPDs appear not to have any phenotypic consequence (Kotzot, 2002).

As an example for chromosome 11, mosaic segmental upd(11p)pat are described as the cause of about $20 \%$ of sporadically occurring cases of Beckwith-Wiedemann-Syndrome (Li et al., 1998; Engel et al., 2000; Maher and Reik, 2000; Gardner et al., 2012). This chromosomal region, located at $11 \mathrm{p} 15$, differs from the detected region 11p11.2p11.12. It is presumed that a segmental UPD, arising postzygotically and being karyotypically 46,XX or $46, X Y$, would imply no risk. Also, UPD due to rearrangement would have a risk according to the nature of the specific rearrangement (Gardner et al., 2012).

\section{Conclusions}

GTG-banding, SKY, locus-specific FISH and SNP array analyses were applied to obtain profiles on different aspects of genetic stability of investigated 2D and 3D chondrocyte cultures. These techniques illuminated different aspects of the cell genomes. With the used sample size, it was not possible to derive statistically significant statements. Also, the average age (65 years) of the patients in this study was different from the Spherox ${ }^{\circledR}$ inclusion criteria's (18-55 years). Despite these limitations, a combination of different (molecular) cytogenetic techniques was used to increase the knowledge and experience on potential cellular therapies and to shape the quality and safety of (combined) ATMPs. Genetic analyses identified chromosomal instability, especially for longer cultivation time, above P 3 . With increasing cultivation time, both numeric and structural (patient 2, 73 year-old) chromosomal aberrations occurred, partially also clonally present in the form of polysomy. In patient 2, from P 1 onwards, chromosomal changes, already described for EMC, were identified. Based on the observations made, it is suggested that the influence of PDLs and age of donor on genetic stability should be evaluated when producing an ATMP. This should include starting materials entrance examination. Cytogenetic analysis of starting material may become a safety measure for each patient.
The meaning of gonosomal losses in older patients in connection with cellular therapies should be further investigated. However, this only partially applies to the GMP production process of Spherox ${ }^{\circledR}$, for which the actual age range is of 18-55 years (Niemeyer et al., 2013). Due to the occurrence of more than $10 \%$ of polyploid cells in a culture vessel of P 2 cells from patient 2, it should be considered whether genetic safety controls at manufacturing and cultivation relevant time points should be performed. GTG-banding, FISH (locus-specific FISH), SKY and SNP array would be appropriate genetic methods, if possible. According to the current state of knowledge (Barkholt et al., 2013) and the collected data in the present study, high-resolution genome wide SNP array analysis should be performed in the non-clinical research program at productionrelevant time points as part of quality investigations. In general, in addition to the analyses of these cells, it is recommended that the peripheral lymphocytes of the donors are collected and analysed to rule out the potential presence of hereditary chromosomal events. In general, chromosomal aberrations were identified (as single events and/or clonally), suggesting that monitoring genetic stability should be part of the characterisation within the field of cell therapy.

\section{Acknowledgements}

The authors (excluding G.C. Bulwin and J.J. Smink) have no commercial, proprietary or financial interest in the products or companies described in this article. G.C. Bulwin and J. J. Smink are employees of co.don ${ }^{\circledR}$ AG. M. Wallenborn, O. Petters, D. Rudolf, H. Hantmann, M. Richter, L. Rohani, P. Ahnert, W. Krupp, R. M. Schulz and H. Holland have no competing interests. H. Holland is supported by the German Federal Ministry of Education and Research (BMBF, grant 1315883, URL: https://www.bmbf. de/en/index.html) and Saxon Ministry of Science and Fine Arts (SM WEEKS, URL: http://www.sm weeks.sachsen.de/). P. Ahnert is funded by the Leipzig Interdisciplinary Research Cluster of Genetic Factors, Clinical Phenotypes and Environment (LIFE Centre, University of Leipzig, Leipzig, Germany). LIFE Centre is funded by the European Union, the European Regional Development Fund (ERFD), the European Social Fund and the Free State of Saxon within the framework of the excellence initiative. R.M. Schulz and O. Petters are also funded by the Saxon Ministry of Science and Fine Arts (SM WEEKS, grant 100243759) and by the German Federal Ministry of Education and Research (BMBF) within the framework of biotechnology and life sciences (grant 100208662). The funders had no role in the study design, data collection and analysis, decision to publish or preparation of the manuscript. All relevant data are within the paper. Additional data are available upon request to the corresponding author. 


\section{References}

Anderer U, Libera J (2002) In vitro engineering of human autogenous cartilage. J Bone Miner Res 17: 1420-1429.

Andriani GA, Vijg J, Montagna C (2017) Mechanisms and consequences of aneuploidy and chromosome instability in the aging brain. Mech Ageing Dev 161: 19-36.

Barkholt L, Flory E, Jekerle V, Lucas-Samuel S, Ahnert P, Bisset L, Buscher D, Fibbe W, Foussat A, Kwa M, Lantz O, Maciulaitis R, Palomaki T, Schneider CK, Sensebe L, Tachdjian G, Tarte K, Tosca L, Salmikangas P (2013) Risk of tumorigenicity in mesenchymal stromal cell-based therapies-bridging scientific observations and regulatory viewpoints. Cytotherapy 15: 753-759.

Boyle AJ, Schulman SP, Hare JM, Oettgen P (2006) Is stem cell therapy ready for patients? Stem cell therapy for cardiac repair. Ready for the next step. Circulation 114: 339-352.

Brittberg M (2012) Autologous chondrocyte implantation. In: Cartilage repair: clinical guidelines decision making in cartilage repair - variables influencing the choice of treatment. Brittberg $M$, Gobbi A, Imhoff AB, Kon E, Madry H, edition. DJO Publications, $1^{\text {st }}$ edition, Guildford, UK: 49-56.

Buddingh EP, Krallman P, Neff JR, Nelson M, Liu J, Bridge JA (2003) Chromosome 6 abnormalities are recurrent in synovial chondromatosis. Cancer Genet Cytogenet 140: 18-22.

Castellanos MV, Hernandez JM, Ramos L, Belen Gonzalez M, Gutierrez NC, Leone PE, Lumbreras E, Robledo C, Garcia Hernandez JL (2004) Chromosomal abnormalities are related to location and grade of osteoarthritis. Osteoarthritis Cartilage 12: 982-985.

Chapiro E, Antony-Debre I, Marchay N, Parizot C, Lesty C, Cung H-A, Mathis S, Grelier A, Maloum K, Choquet S, Azgui Z, Uzunov M, Leblond V, MerleBeral H, Sutton L, Davi F, Nguyen-Khac F (2014) Sex chromosome loss may represent a disease-associated clonal population in chronic lymphocytic leukemia. Genes Chromosomes Cancer 53: 240-247.

Engel JR, Smallwood A, Harper A, Higgins MJ, Oshimura M, Reik W, Schofield PN, Maher ER (2000) Epigenotype-phenotype correlations in BeckwithWiedemann syndrome. J Med Genet 37: 921-926.

Gardner RJM, Sutherland GR, Shaffer LG (2012) Chromosome abnormalities and genetic counseling, Oxford University Press, Oxford, New York, pp 320, 330-331, 400-401.

Guttenbach M, Koschorz B, Bernthaler U, Grimm T, Schmid M (1995) Sex chromosome loss and aging: in situ hybridization studies on human interphase nuclei. Am J Hum Genet 57: 1143-1150.

Hameed M, Ulger C, Yasar D, Limaye N, Kurvathi R, Streck D, Benevenia J, Patterson F, Dermody JJ, Toruner GA (2009) Genome profiling of chondrosarcoma using oligonucleotide array-based comparative genomic hybridization. Cancer Genet Cytogenet 192: 56-59.
Heldin C-H (2013) Targeting the PDGF signaling pathway in tumor treatment. Cell Commun Signal 11: 97.

Holland H, Ahnert P, Koschny R, Kirsten H, Bauer M, Schober R, Meixensberger J, Fritzsch D, Krupp W (2012) Detection of novel genomic aberrations in anaplastic astrocytomas by GTG, SKY, locus-specific FISH, and high density SNP-array. Pathol Res Pract 208: 325-330.

Hunziker EB, Lippuner K, Keel, M J B, Shintani N (2015) An educational review of cartilage repair: precepts \& practice-myths \& misconceptionsprogress \& prospects. Osteoarthritis Cartilage 23: 334-350.

Kawasaki RS, Caldeira LF, Andre FS, Gasques JA, Castilho WH, Bozola AR, Thome JA, Tajara EH (1991) Multiple cytogenetic clones in a basal cell carcinoma. Cancer Genet Cytogenet 54: 33-38.

Kotzot D (2002) Supernumerary marker chromosomes (SMC) and uniparental disomy (UPD): coincidence or consequence? J Med Genet 39: 775-778.

La Fuente R de, Abad JL, Garcia-Castro J, Fernandez-Miguel G, Petriz J, Rubio D, VicarioAbejon C, Guillen P, Gonzalez MA, Bernad A (2004) Dedifferentiated adult articular chondrocytes: a population of human multipotent primitive cells. Exp Cell Res 297: 313-328.

Li M, Squire JA, Weksberg R (1998) Molecular genetics of Wiedemann-Beckwith syndrome. Am J Med Genet 79: 253-259.

Maher ER, Reik W (2000) Beckwith-Wiedemann syndrome: imprinting in clusters revisited. J Clin Invest 105: 247-252.

McGowan-Jordan J, Simons A, Schmid M (2016) ISCN: An international system for human cytogenomic nomenclature. Karger, Basel, New York, pp 8, 39.

Morrison C, Radmacher M, Mohammed N, Suster D, Auer H, Jones S, Riggenbach J, Kelbick N, Bos G, Mayerson J (2005) MYC amplification and polysomy 8 in chondrosarcoma: array comparative genomic hybridization, fluorescent in situ hybridization, and association with outcome. J Clin Oncol 23: 9369-9376.

Niemeyer P, Andereya S, Angele P, Ateschrang A, Aurich M, Baumann M, Behrens P, Bosch U, Erggelet C, Fickert S, Fritz J, Gebhard H, Gelse K, Günther D, Hoburg A, Kasten P, Kolombe T, Madry H, Marlovits S, Meenen NM, Müller PE, Nöth U, Petersen JP, Pietschmann M, Richter W, Rolauffs B, Rhunau K, Schewe B, Steinert A, Steinwachs MR, Welsch GH, Zinser W, Albrecht D (2013) Stellenwert der autologen Chondrozytentransplantation (ACT) in der Behandlung von Knorpelschäden des Kniegelenks - Empfehlungen der AG Klinische Geweberegeneration der DGOU. Zeitschrift für Orthopädie und Unfallchirurgie 151: 38-47.

Nikitina VA, Osipova EY, Katosova LD, Rumyantsev SA, Skorobogatova EV, Shamanskaya TV, Bochkov NP (2011) Study of genetic stability of human bone marrow multipotent mesenchymal stromal cells. Bull Exp Biol Med 150: 627-631. 
Nishio J, Iwasaki H, Nabeshima K, Naito M (2011) Cytogenetics and molecular genetics of myxoid softtissue sarcomas. Genet Res Int 2011: 497148.

O'Keefe C, McDevitt MA, Maciejewski JP (2010) Copy neutral loss of heterozygosity: a novel chromosomal lesion in myeloid malignancies. Blood 115: 2731-2739.

Ostman A, Yang Q, Tonks NK (1994) Expression of DEP-1, a receptor-like protein-tyrosine-phosphatase, is enhanced with increasing cell density. Proc Natl Acad Sci U S A 91: 9680-9684.

Pierre RV, Hoagland HC (1972) Age-associated aneuploidy: loss of $Y$ chromosome from human bone marrow cells with aging. Cancer 30: 889-894.

Reimann-Berg N, Murua Escobar H, Kiefer Y, Mischke R, Willenbrock S, Eberle N, Nolte I, Bullerdiek J (2011) Cytogenetic analysis of CpGoligonucleotide DSP30 plus Interleukin-2-Stimulated canine B-Cell lymphoma cells reveals the loss of one $\mathrm{X}$ Chromosome as the sole abnormality. Cytogenet Genome Res 135: 79-82.

Russell LM, Strike P, Browne CE, Jacobs PA (2007) $\mathrm{X}$ chromosome loss and ageing. Cytogenet Genome Res 116: 181-185.

Shaffer LG (2013) Recommendations of the International standing committee on human cytogenetic nomenclature. Karger, Basel, Freiburg, pp 7, 41 .

Sjögren H, Meis-Kindblom JM, Orndal C, Bergh P, Ptaszynski K, Aman P, Kindblom L-G, Stenman G (2003) Studies on the molecular pathogenesis of extraskeletal myxoid chondrosarcoma-cytogenetic, molecular genetic, and cDNA microarray analyses. Am J Pathol 162: 781-792.

Stumm M, Boger E, Gaissmaier CG, Osswald C, Blankenburg M, Wegner RD, Mollenhauer JA (2012) Genomic chondrocyte culture profiling by array$\mathrm{CGH}$, interphase-FISH and RT-PCR. Osteoarthritis Cartilage 20: 1039-1045.

Takahashi T, Takahashi K, St John PL, Fleming PA, Tomemori T, Watanabe T, Abrahamson DR, Drake CJ, Shirasawa T, Daniel TO (2003) A mutant receptor tyrosine phosphatase, CD148, causes defects in vascular development. Mol Cell Biol 23: 1817-1831.

Therman E (1995) Chromosome behavior in cell differentiation: a field ripe for exploration?. Genetics 141: 799-804.

Trimborn M, Endres M, Bommer C, Janke U, Kruger J-P, Morawietz L, Kreuz PC, Kaps C (2012) Karyotyping of human chondrocytes in scaffoldassisted cartilage tissue engineering. Acta Biomater 8: 1519-1529.

Wiktor A, Rybicki BA, Piao ZS, Shurafa M, Barthel B, Maeda K, van Dyke DL (2000) Clinical significance of $Y$ chromosome loss in hematologic disease. Genes Chromosomes Cancer 27: 11-16.

Williams R, Khan IM, Richardson K, Nelson L, McCarthy HE, Analbelsi T, Singhrao SK, Dowthwaite GP, Jones RE, Baird DM, Lewis H, Roberts S, Shaw HM, Dudhia J, Fairclough J, Briggs T, Archer CW (2010) Identification and clonal characterisation of a progenitor cell sub-population in normal human articular cartilage. PLoS One 5: e13246.

Xu L-X, Holland H, Kirsten H, Ahnert P, Krupp W, Bauer M, Schober R, Mueller W, Fritzsch D, Meixensberger J, Koschny R (2015) Three gangliogliomas: results of GTG, SKY, genome-wide high resolution SNP-array, gene expression and review of the literature. Neuropathology 35: 148-157.

Yeh JI, Levine AS, Du S, Chinte U, Ghodke H, Wang H, Shi H, Hsieh CL, Conway JF, van Houten B, Rapic-Otrin V (2012) Damaged DNA induced UV-damaged DNA-binding protein (UV-DDB) dimerization and its roles in chromatinized DNA repair. Proc Natl Acad Sci U S A 109: 46.

\section{Discussion with reviewer}

Sylvie Miot: Since biopsies of articular cartilage were harvested from an undamaged area of patients with osteoarthritis, can chondrocytes still be considered as healthy cells or is there a probability that these cells already present an abnormal genetic profile?

Authors: Only few cytogenetic reports from patients with osteoarthritis are published (Broberg et al., 1997, additional reference; Mertens et al., 1996, additional reference; Castellanos et al., 2004). Trisomy X, Y, 5 , and 7 are described in osteoarthritic cartilage of grade II to IV, according to the Kellgren and Lawrence Score (KLS) (Kellgren and Lawrence, 1957, additional reference). To the best of our knowledge, clonal chromosomal aberrations are not known for healthy as well as KLS grade I osteoarthritic cartilage. The majority of the chondrocyte-based ATMPs contraindicate the implantation of an (M)ACI product into joints with an KLS grade III and IV. Taken into account this exclusion criteria and the above stated literature, it might be possible that cartilage samples harvested from patients with KLS II exhibit a higher probability for numeric aberrations.

Sylvie Miot: Which additional quality control measure would you include during GMP manufacturing of a chondrocytes-based ATMP, in order to increase the patient safety?

Authors: Currently, many powerful genetic techniques are available for evaluating the genetic stability in cell therapy, including conventional GTGbanding, SKY, FISH, CGH or SNP, whole genome sequencing (NGS), gene expression analyses and epigenetics. Each of these techniques has its own advantages and limitations. Thus, it is frequently valuable to use a combination of conventional karyotyping and molecular (cyto)genetic techniques as complementary tools to evaluate genomic stability. In order to increase the patient safety, it is advised to include GTG-banding, SKY, SNP array, NGS and gene expression analyses (at different time points) as quality control measure system within the GMP-process validation study of the respective ATMP. Finally, a decision on the preferable genetic 
stability quality control method(s) should be made, based on the observed product-specific (numeric and structural) genetic instabilities. Moreover, the optimal validated quality control method for product release shall be a fast and simple method that enables the immediate release of the cellular product. Based on the herein described case study on Spherox ${ }^{\circledR}$, it is advised to include both, SKY and FISH, for the product release of Spherox ${ }^{\circledR}$.

\section{Additional References}

Broberg K, Limon J, Pålsson E, Lindstrand A, Toksvig-Larsen S, Mandahl N, Mertens F (1997) Clonal chromosome aberrations are present in vivo in synovia and osteophytes from patients with osteoarthritis. Genet 101: 295-298.

Kellgren JH, Lawrence JS (1957) Radiological assessment of osteo-arthrosis. Ann Rheum Dis 16: 494-502.

Mertens F, Pålsson E, Lindstrand A, ToksvigLarsen S, Knuutila S, Larramendy ML, el-Rifai W, Limon J, Mitelman F, Mandahl N (1996) Evidence of somatic mutations in osteoarthritis. Hum Genet 98: 651-656.

Editor's note: The Scientific Editor responsible for this paper was Martin Stoddart. 